\title{
Characteristics of the Atlantic Herring (Clupea harengus L.) Spawning Population Along the Maine Coast, Inferred from Larval Studies
}

\author{
Joseph J. Graham, Bruce J. Joule and Curt L. Crosby \\ Maine Department of Marine Resources Fishery Research Laboratory \\ West Boothbay Harbor, Maine, USA 04575 \\ and \\ David W. Townsend \\ Bigelow Laboratory for Ocean Sciences \\ West Boothbay Harbor, Maine, USA 04575
}

\begin{abstract}
Characteristics of the spawning population of Atlantic herring along the Maine coast are inferred from an examination of larval catch rates and the distribution of larval cohorts based on otolith growth increments. Comparison of larval catch rates with the harvests of adult herring indicated that larval production decreased precipitously in 1978 following the removal of the 1970 year-class from the coastal spawning population and a general increase in the catch of adults. Reduced larvai production persisted after 1978 and reached a low level in 1981 which resulted in the collapse of the fishery for juveniles (age 2) in 1983. Comparison of catch rates from larval surveys along the coast and the occurrence of larval cohorts inshore during 1980-81 with those reported for the mid-1960's and early 1970's indicated little change in the location of spawning grounds and the presence of larval cohorts, but the mechanisms which enhance larval survival and recruitment were probably not the same for the spawning grounds off eastern and central-western Maine. It is suggested that the survival of larvae hatched in the eastern area was increased by their dispersion westward along the coast to overwinter in the many estuaries and embayments, whereas larvae hatched in the central-western area were less widely dispersed but their survival was increased by the shorter winter experienced by some because of late spawning. The absence of late spawning in the central-western area in 1981, evident from the absence of larval cohorts inshore during the winter, was probably responsible in part for the very small catch of juvenile herring in 1983. The implications of reducing the spawning population below some critical level by intensive harvesting of weak year-classes are discussed in relation to management problems.
\end{abstract}

\section{Introduction}

The herring fishery has been a major industry of Maine for about 100 years. The harvest of juvenile herring (ages 1-3) in the Gulf of Maine began in the late 1800 's, and that of adults (age 4 and older) was a more recent development. Annual catches of juveniles varied from 34,400 to 90,600 (metric) tons during the 1950's but declined to a low of 6,500 tons by 1971 . During 1974-82, the annual harvest fluctuated between 12,700 and 37,400 tons. Anthony and Waring (1980) reported that the fishery for adult herring in the Gulf of Maine began with a catch of 7,000 tons in 1967 and developed rapidly to yield an average of 38,500 tons annually during 1969-72, as the accumulated stock of old fish was harvested. Catches then declined rapidly, averaging 18,700 tons during 1972-77. During 1978-82, catches of adults have averaged 25,100 tons (Fogarty and Clark, MS 1983). The primary site of the fishery for adult herring, which occurs in summer and autumn, is in the vicinity of Jeffreys Ledge off western Maine (Fig. 1). However, the increase in the average harvest since 1978 was primarily from increased catches along the Maine coast.
Herring spawn during late summer and autumn in coastal waters near the headlands along the Maine coast. Hatching of larvae occurs in three major areas or spawing grounds: (a) off Machias Bay in eastern Maine, (b) off Boothbay in central Maine, and (c) off Saco Bay in western Maine (Fig. 1). After hatching off eastern Maine, the larvae are transported westward along the coast, entering the many estuaries and embayments at least as far as the Boothbay area (Graham, 1982). Those hatched off central and western Maine are transported shoreward into the estuaries and embayments generally adjacent to the hatching areas. In this paper, some characteristics of herring spawning off eastern and central Maine are inferred from an examination of larval catch rates and the distribution of larval cohorts based on a study of otolith growth increments.

\section{Materials and Methods}

Collections of larval herring have been made along the Maine coast from tidal flows in estuaries with buoyed and anchored nets since the early 1960's to 


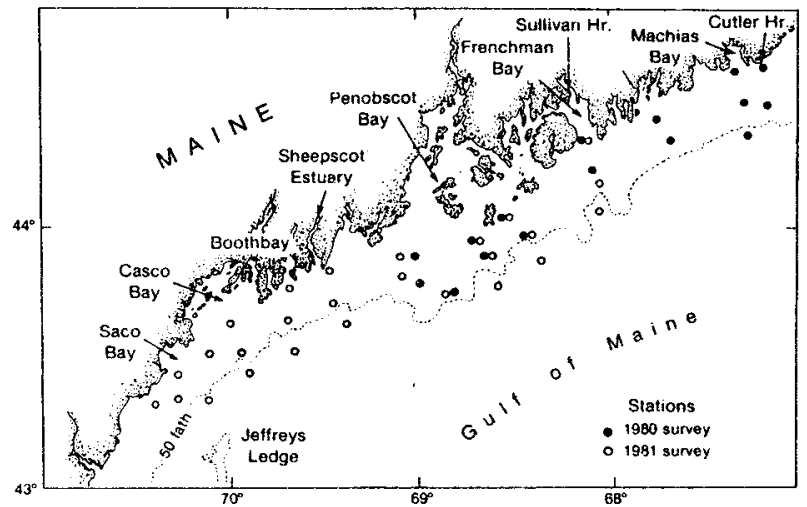

Fig. 1. Station positions for larval herring surveys along the Maine coast in 1980-81 and locations of various places mentioned in the text.

anticipate recruitment to the fishery for juveniles and, in recent years, to evaluate the status of the spawning populations. Larval surveys of coastal waters with towed nets have also been made to obtain information on the distribution of spawning herring from the occurrence of newly-hatched larvae (Graham, 1982).

The abundances of larval herring in two inshore areas were estimated from the catches of buoyed and anchored nets in the Sheepscot estuary of central Maine and the Sullivan Harbor embayment of eastern Maine (Fig. 2). The sampling designs and operation of the nets in both areas have been described previously (Graham and Joule, MS 1981; Graham, 1982). The relative abundance of larval herring from an overnight set of the nets was expressed as the number caught per $100 \mathrm{~m}^{3}$ of water strained. To compare peak catch rates in autumn over a number of years, the data were partitioned according to the sampling design of Graham (1972) and subjected to a Kruskal-Wallis test (Zar, 1974) followed by Dunn's (1964) multiple comparison test.

The relative distributions of larval herring along the Maine coast in 1980 and 1981 were estimated from data collected during surveys with towed nets. The results of these surveys were compared with those of 1972, which were reported previously by Graham (1982). At each station in 1972, a single continuous oblique tow from near-bottom depth or $100 \mathrm{~m}$ was made with a metered $61-\mathrm{cm}$ Bongo sampler containing $0.505 \mathrm{~mm}$ mesh nets and the catch rate (No. $/ \mathrm{m}^{2}$ ) was calculated as the number of larvae under a square meter of sea surface. The recent surveys were conducted with the same gear at the same towing velocity ( $2 \mathrm{~m} / \mathrm{sec}$.), but two oblique tows were made at each station to maximum depths of $20 \mathrm{~m}$ in 1980 and $40 \mathrm{~m}$ in 1981. Because these tows were not made from bottom to surface, catch rates were calculated as the number of larvae caught per $100 \mathrm{~m}^{3}$ of water strained. Thus, the

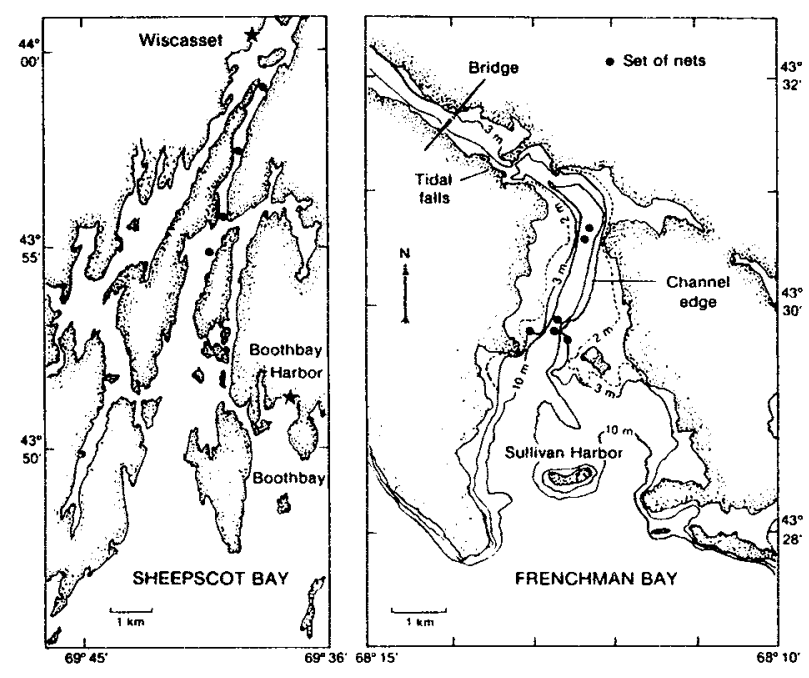

Fig. 2. Station positions of buoyed and anchored nets in the Sheeps. cot estuary and in Sullivan Harbor.

comparisons are limited to the relative distributions of larvae. However, recent data expressed as No. $/ \mathrm{m}^{2}$ (Graham et al., MS 1983) support the comparisons.

During autumn and winter of $1980 / 81$ and $1981 / 82$, samples of organisms from the buoyed and anchored nets were stored in ice and brought to the laboratory where the larval herring were sorted. Usually 10 larvae were removed from each sample and frozen for subsequent examination, but larger numbers were taken from some samples when the overall catch was small in order to offset the paucity of larvae in other samples from a given set of nets. During a coastal survey in 1981, larval herring were sorted from the samples aboard ship and then frozen.

Procedures for processing the otoliths of larval herring and counting their microstructural growth increments were those reported by Townsend and Graham (1981). Two counts were made on an otolith from each larva, and these were averaged when the difference between them did not exceed $5 \%$ of the largest count: otherwise, the counts were rejected. Usually, the difference did not exceed three increments. Frequency distributions of the estimated date on which the first increment was formed in each otolith were smoothed by a running-average of three. The date of such an initial increment was back-calculated by assuming that an increment was formed each day after yolk-sac absorption. Published experimental results both agreed (Gjoseter, MS 1981; Gjoseter and $\varnothing$ iested, MS 1981) and disagreed (Lough et al., 1982; Geffen, 1982) with the assumption that growth increments are formed daily. Townsend and Graham (1981) assumed a daily periodicity of growth increments in otoliths of larvae from the Sheepscot estuary, with evidence of relatively fast growth in the autumn and 
slow growth after late January or early February. Graham et al. (1972), using modal lengths, found that the period of slow growth was the same for two cohorts of larval herring examined by them. During the present study, the growth rate of a cohort during the period of fast growth (19 October-4 December) was calculated from modal lengths of larvae sampled independently of those used for otolith analysis. After transforming the modal lengths from standard to total lengths, the growth rate derived from the progression of modal lengths $(2.5 \mathrm{~mm} / \mathrm{wk})$ was identical to that derived from aged larvae for about the same period. Although there may be within-season differences in the addition of increments, such differences were assumed to be constant. Thus, the range in dates of first increment formation is an approximation, but it fits well with other information on larval herring from Maine coastal waters (Graham et al., 1972; Graham, 1982). In this paper, a cohort is considered to be a group of larvae whose initial increments are distributed over a brief period (weeks) within the smoothed distributions.

\section{Results}

\section{Inshore catch rates}

Peaks in larval abundance are evident in inshore waters after the herring eggs begin hatching in late August and early September along the Maine coast. Available data from peristent sampling in the Sheepscot estuary during autumn in 1964, 1966-69 and 1973-81 were examined to see if larval catch rates (Table 1) reflected variations in either the size or the reproductive efficiency of the coastal spawning populations. It is evident that peaked catch rates fluctuated considerably (Fig. 3). A Kruskal-Wallis test indicated that the magnitudes of the peaks differed significantly $(P<0.01)$. Application of Dunn's multiple comparison test indicated that the difference was between the high and low values of the year-classes. However, the difference was perhaps symptomatic of four substantial

TABLE 1. Summary of peak catch rates of larval herring in the Sheepscot estuary, 1964-81.

\begin{tabular}{llrr}
\hline $\begin{array}{l}\text { Year- } \\
\text { class }\end{array}$ & $\begin{array}{c}\text { Date of } \\
\text { peak }\end{array}$ & $\begin{array}{r}\text { No. of } \\
\text { larvae }\end{array}$ & $\begin{array}{r}\text { No. per } \\
100 \mathrm{~m}^{3}\end{array}$ \\
\hline 1964 & 22 Oct & 2,057 & 16.15 \\
1966 & 21 Nov & 3,056 & 17.30 \\
1967 & 08 Nov & 3,829 & 19.71 \\
1968 & 29 Oct & 4,387 & 55.27 \\
1969 & 23 Oct & 3,679 & 20.28 \\
1973 & 08 Nov & 5,068 & 23.11 \\
1974 & 30 Oct & 3,997 & 18.63 \\
1975 & 06 Nov & 9,194 & 32.50 \\
1976 & 18 Oct & 2,234 & 14.00 \\
1977 & 20 Oct & 32,645 & 79.38 \\
1978 & 16 Nov & 1,133 & 3.81 \\
1979 & 08 Nov & 3,148 & 9.56 \\
1980 & 11 Dec & 2,251 & 8.56 \\
1981 & 19 Oct & 590 & 2.84 \\
\hline
\end{tabular}

changes in larval life history which occurred over the entire span of 13 year-classes: (a) the 1966-73 yearclasses had moderately high peak catch rates in autumn, followed by a gradual decline in winter; (b) the 1974-76 year-classes had peak catch rates in autumn, followed by somewhat smaller peaks in winter (Fig. 4), due to late spawning and hatching in late autumn and early winter (Townsend and Graham, 1981; Graham, 1982); (c) the peak catch rate in 1977 exceeded all others (Fig. 3) and late spawning was not evident; and (d) this peak catch rate was followed by a series of low rates in 1978-81 (Fig. 4), with considerable variation in the time of their occurrence. in 1978 and 1979, the peak occurred in November and the 1979 year-class exhibited small increases in December and early January, but the peak in 1980 did not occur until December. In 1981 , the peak was the lowest of the time series and occurred in October, with little evidence of later spawning. The increase in catch rate for the 1980 yearclass in February was related to an early spring aggregation of larvae rather than to late spawning (Fig. 4). From the Dunn's multiple comparison test, the low catch rates of the 1978-81 year-classes were, as a

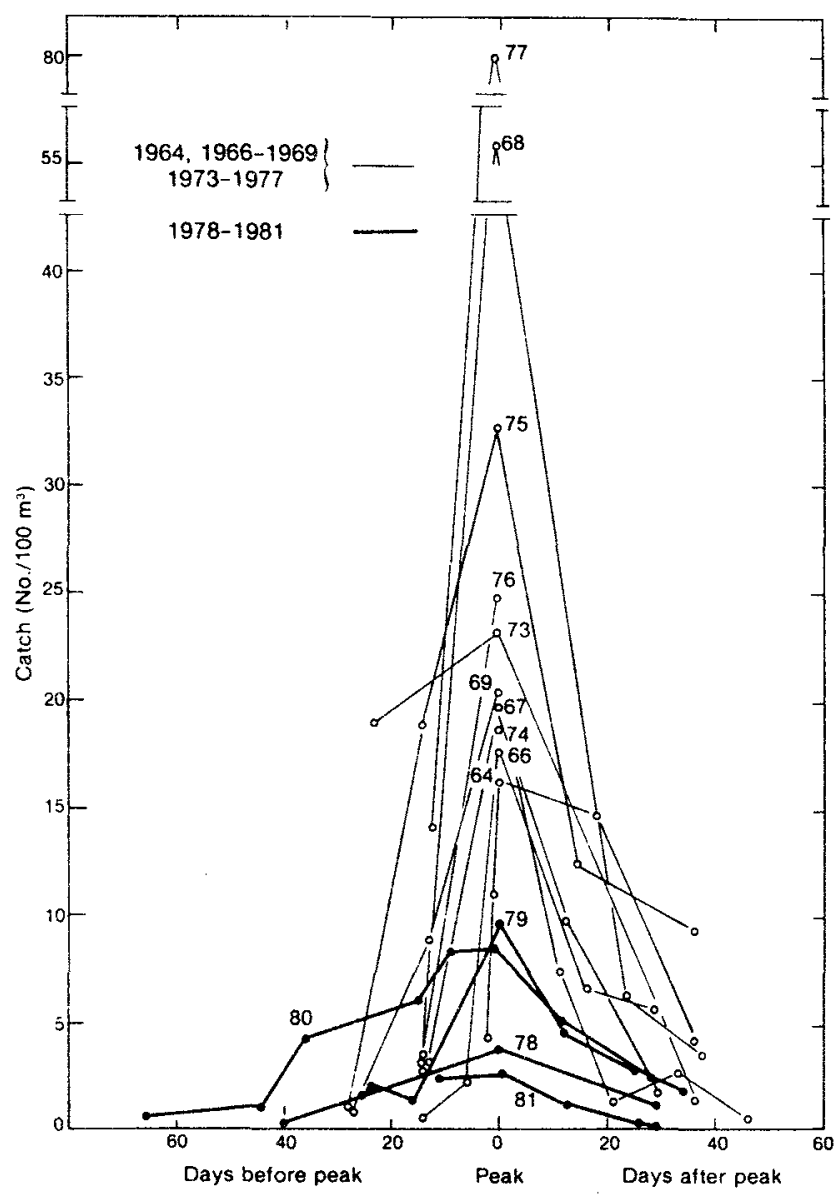

Fig. 3. Peak catch rates of larval herring in the Sheepscot estuary in various years of the 1964-81 period. (The date for each peak catch rate is set at zero and rates preceding and following each peak are plotted in days; dates of the peaks are given in Table 1.) 


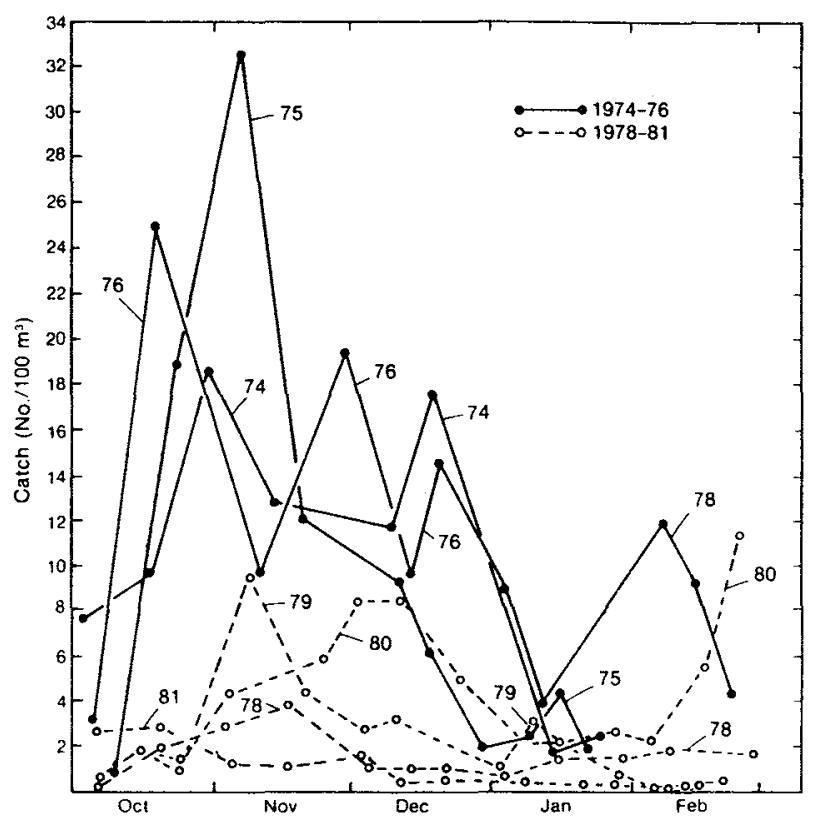

Fig. 4. Catch rates of larval herring in the Sheepscot estuary during autumn and winter of years when late (November) spawning occurred, 1974-76 and 1978-81. (Dashed lines indicate years of low larval production.)

group, not statistically compatible with the other groups $(P<0.05)$, indicating a severe and sustained decline in larval production.

Although only 4 years of data are available for Sullivan Harbor in eastern Maine, the autumn catch rates in 1973 and 1974 exhibited declines similar to those for larvae in the Sheepscot estuary (Fig. 5). Sampling did not begin as early in 1973-74 as it did in 1980-81, but it was sufficient to indicate peaks in early autumn catch rates that were large compared to those of the latter period. In 1980, the catch rate increased only slightly from no larvae in September to comparatively small peak values in late October and early November and declined to insignificant values after mid-November. In 1981, the catch rate fluctuated during late September and October, with increasing tendency to a peak in late November, which was similar to the mid-November catch rates in 1973-74, and the level maintained in December 1980 was also similar to that for the earlier period.

\section{Coastal catch rates}

The absence of larvae in Sullivan Harbor during September 1980 prompted an October survey of coastal waters of eastern Maine to determine if this area was still utilized by herring as a spawning ground. The results of this survey were compared with those from a late September survey in the autumn of 1972 (Graham, 1982) (Fig. 6). The 1980 survey was about 5 weeks later than the 1972 survey, but both occurred approximately one month after hatching began in the area. The rela-

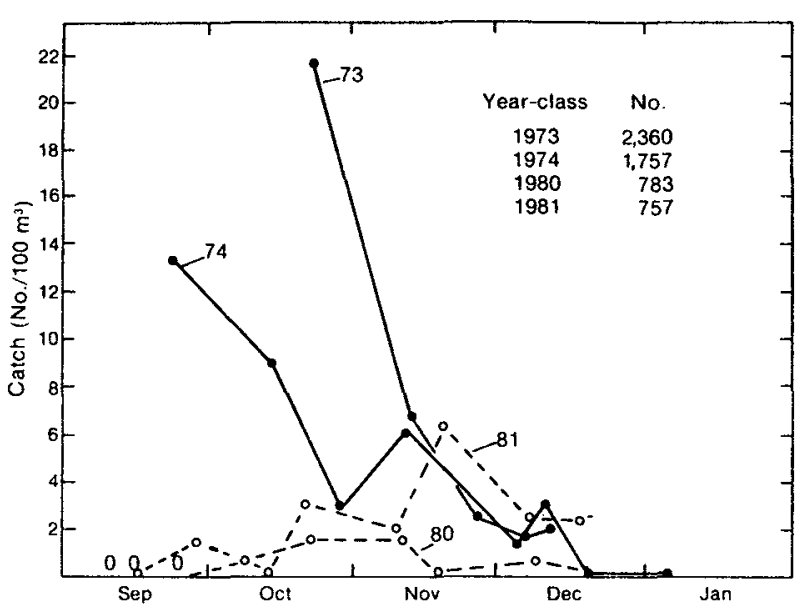

Fig. 5. Catch rates of larval herring in Sullivan Harbor during autumn and winter of 1973-74 (solid lines) and 1980-81 (dashed lines)

tively high catch rates of larvae southeast and southwest of Machias Bay in 1980 indicated that this area was still an important spawning ground. Although sampling techniques were different for the two surveys, some points of agreement in relative larval distribution and abundance were apparent: (a) recently-hatched larvae $(<10 \mathrm{~mm}$ ) were concentrated in the vicinity of Machias Bay; (b) larger larvae (10-15 mm), although less abundant in 1980 than in 1972, were distributed somewhat similarly to the recently-hatched larvae; and (c) the largest larvae $(>15 \mathrm{~mm})$ were relatively abundant near the entrances to embayments and off Penobscot Bay. Essentially, the patterns of larval dispersal in the area, from the results of the two surveys 8 years apart, were quite similar. Possibly, the spawning sites of eastern Maine have been used for many years and their use is continuing. Surveys in the 1960's, with the same sampling methods used in 1980, indicated that recently-hatched larvae were widely distributed off eastern Maine with declining abundance toward Penobscot Bay. Yolk-sac larvae were obtained in the area where recently-hatched larvae were concentrated in 1980. In the autumn of 1982, Graham et al. (MS 1983) found concentrations of recently-hatched larvae in the same area as in 1972, and, in the autumn of 1983, eggs and yolk-sac larvae were also obtained in eastern Maine coastal waters (unpubl. data, Fishery Research Laboratory, Maine).

In 1981, a survey was conducted in centralwestern coastal waters during 27 October -6 November to ascertain the degree of larval hatching in that area. The results from this survey were compared with those from the last survey (6-12 November) of four conducted in 1972 (Graham, 1982). As for the eastern Maine surveys (Fig. 6), the data from the two surveys off central-western Maine 9 years apart (Fig. 7) exhibited some points of agreement: (a) recently-hatched larvae $(<10 \mathrm{~mm}$ ) were present as traces off Casco Bay 

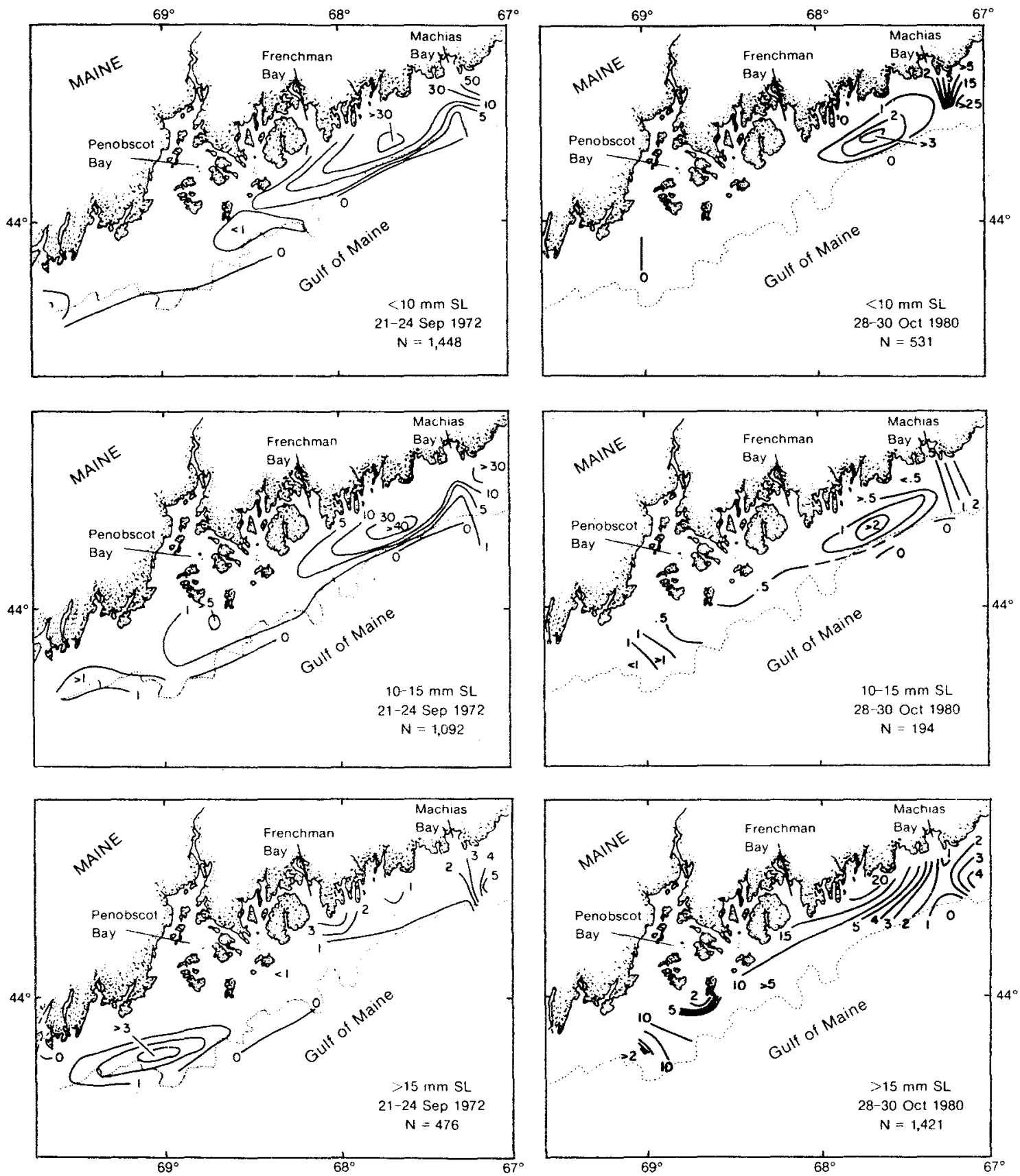

Fig. 6. Contoured distributions of larval herring from surveys along the eastern Maine coast in September 1972 (from Graham, 1982) and in October 1980. (Values for 1972 represent the number of larvae under $\mathrm{a}^{2}$ of sea surface, and those for 1980 are in numbers per $100 \mathrm{~m}^{3}$ of water strained.)

and Saco Bay; (b) larger larvae (10-15 mm) were most abundant west of Penobscot Bay; and (c) concentrations of the largest larvae $(>15 \mathrm{~mm})$ were found off Frenchman Bay and Penobscot Bay. However, disagreement in the results of the two surveys was also apparent, in that the larger larvae (10-15 $\mathrm{mm}$ ) were concentrated near Boothbay in 1972 and near Saco Bay in 1981. This difference in area of concentration was probably due to the timing of the surveys relative to inshore migration of larvae in these years rather than to a major change in distribution, because an earlier survey in 1972 (18-22 October) revealed concentrations of 10-15 mm larvae in both areas (Graham, 1982). The largest larvae $(>15 \mathrm{~mm}$ ) were not as abundant west of Penobscot Bay in 1981 as they were in 1972 (Fig. 7).

\section{Larval cohorts}

Cohorts of larvae were often evident from the distribution of assumed daily growth increments which were determined from otoliths. A sample of larvae from 

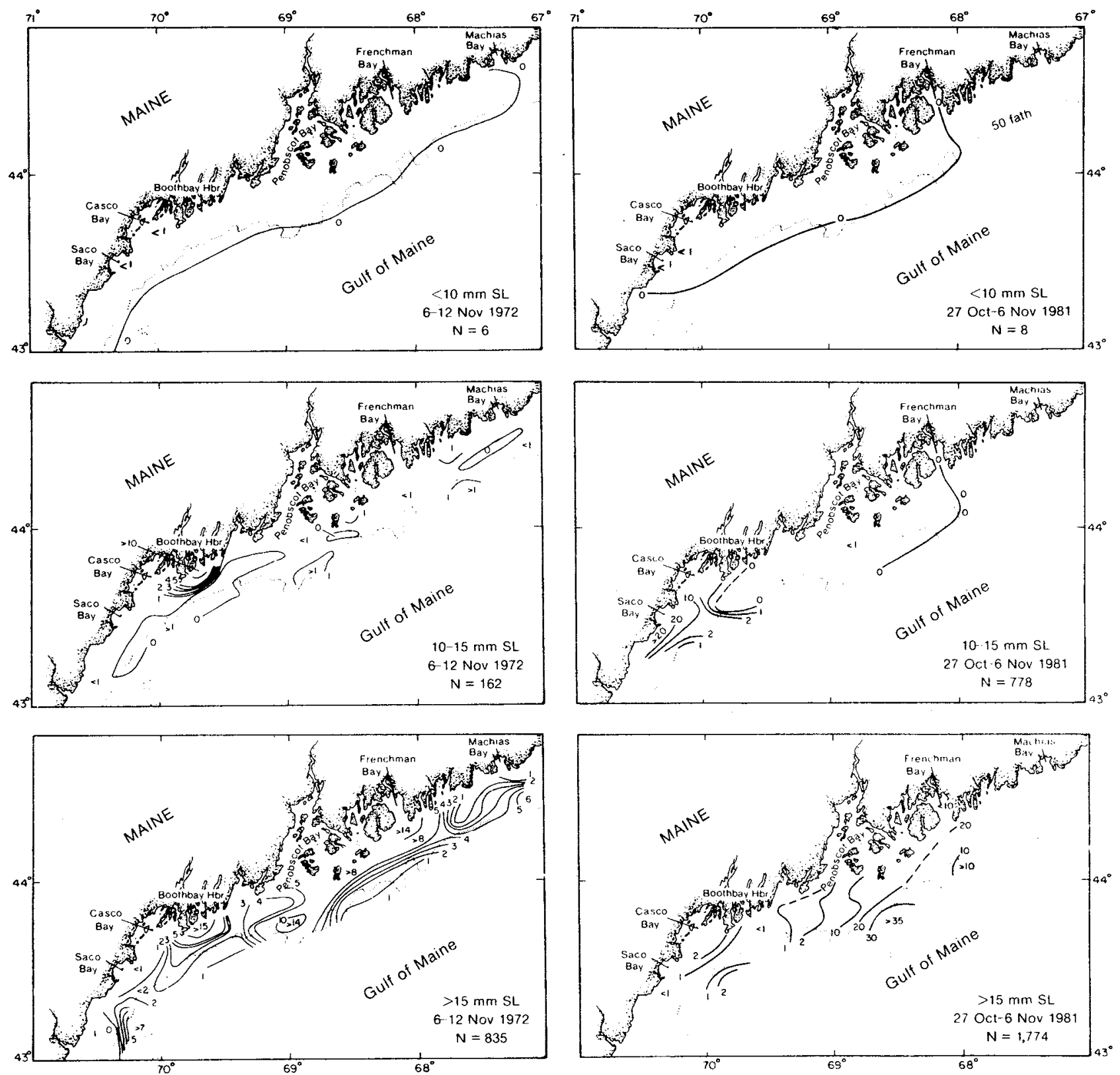

Fig. 7. Contoured distributions of larval herring from surveys along the Maine coast in November 1972 (from Graham, 1982) and in OctoberNovember 1981. (Values as defined in Fig. 6.)

Sullivan Harbor on 8 October 1980 indicated the presence of a cohort which formed its first growth increment in mid-September (Fig. 8). By 21 October, that cohort was poorly represented in the samples and a second one predominated with initial increments which formed in early October. Few otoliths were examined in November and December, but some larvae with first increment formation in mid-October were present.

Cohorts were less precisely defined in the 1980 data from Sheepscot estuary than in the data from Sullivan Harbor. However, five cohorts evidently appeared from October to January (Fig. 9). During
October, cohorts were present with initial increments centered in early and late September. In November, the early September cohort was poorly represented and a new cohort prevailed with initial increments in early October. By December, the September cohorts were practically non-existent and a new cohort was present with initial increments centered in early November. All four earlier cohorts were greatly diminished in January and a single cohort was present with first increments in late November and early December. February data were too few to evaluate the progression of cohorts.

A summary of data for the 1980 year-class (Fig. 10) shows clearly the presence of two cohorts of larvae in 


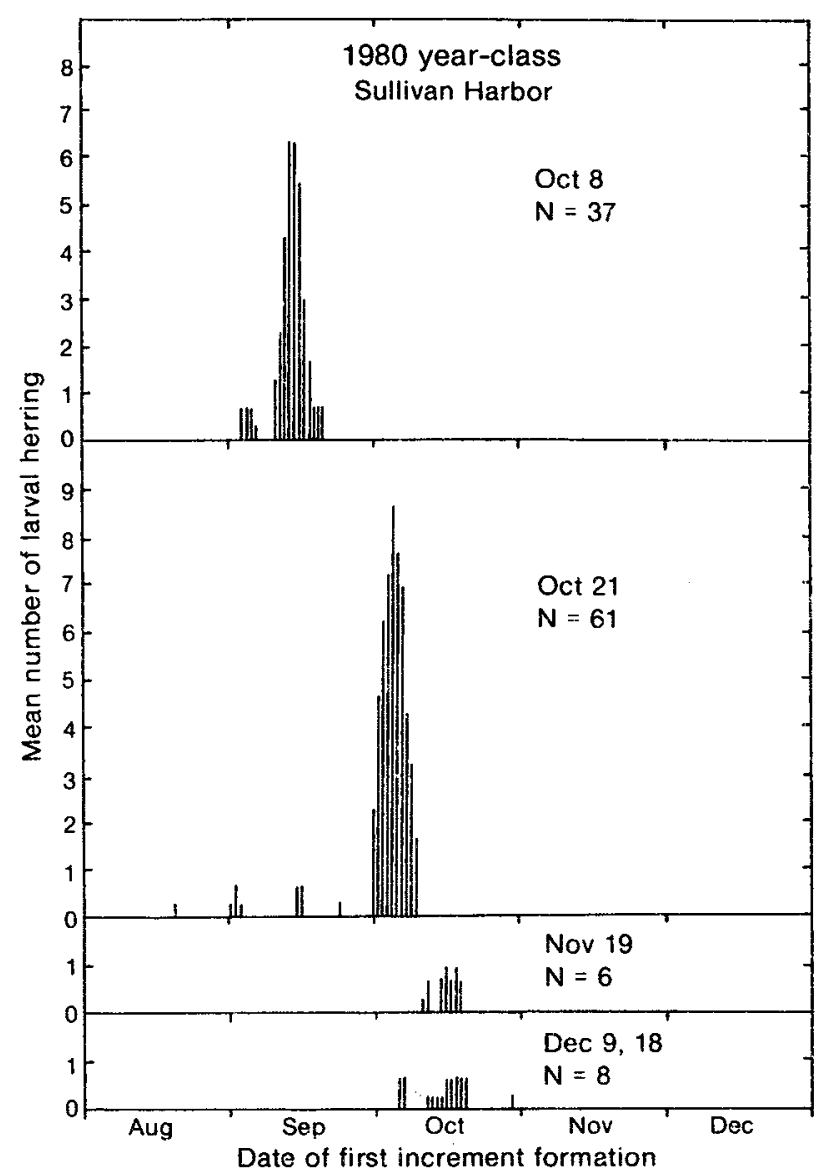

Fig. 8. Frequencies of initial growth increments in otoliths of larval herring from Sullivan Harbor, arranged by month of capture for the 1980 year-class.

September and early October and perhaps the beginning of a third about mid-October in the Sullivan Harbor samples. In the Sheepscot estuary samples, the modes of the three cohorts from early September to early October are widely separated from the two cohorts which formed their first growth increments during November and early December. Essentially, the 1980 data show three striking features: (a) the appearance of cohorts and their subsequent decline; (b) the presence of a dominant cohort in both areas during early October; and (c) the separation of the early (September-October) and late (November-early December) cohorts in Sheepscot estuary into two major groups.

From sampling in 1981, cohorts were not as readily distinguishable as in 1980, but they were persistent. In Sullivan Harbor, the initial increments for larvae captured in late September and October were grouped in September, and those for larvae captured in November and December were grouped in late September and October (Fig. 11). In Sheepscot estuary, initial increments were formed mainly during September for larvae captured in October (Fig. 12), and a second cohort was present in November with initial increments centered in late October. Both groups persisted during Decem-

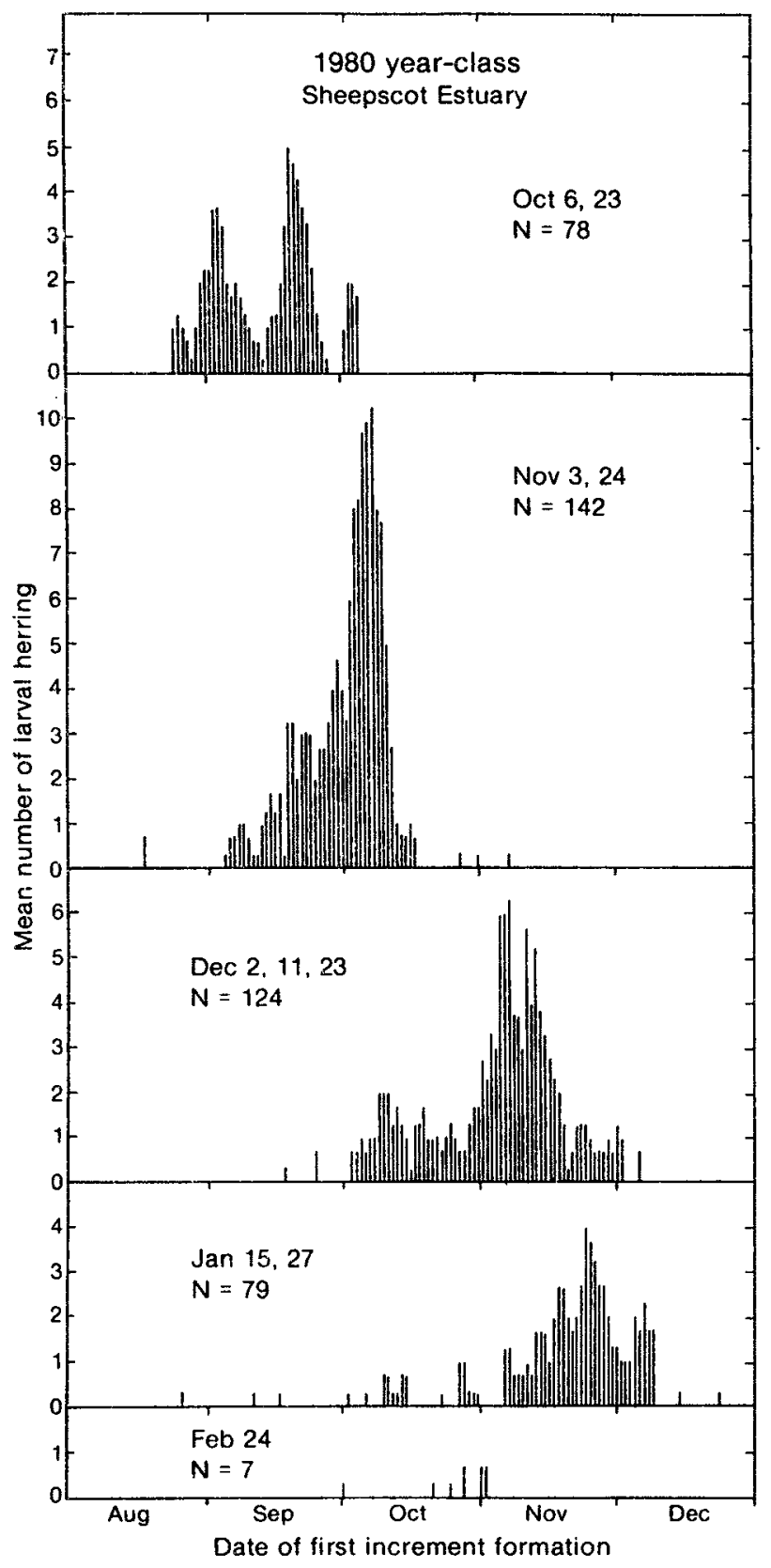

Fig. 9. Frequencies of initial growth increments in otoliths of larval herring from the Sheepscot estuary, arranged by month of capture for the 1980 year-ciass.

ber-February, and there were only traces of larvae with first increment dates later than early November.

Unlike the summarized data for 1980 (Fig. 9), the data for 1981 (Fig. 13) showed neither the coincidence of modal groups in the Sullivan Harbor and Sheepscot estuary data during September and October nor the separation of early (September-October) and late (November-December) groups in the Sheepscot estuary. The distribution of first increment formation in larvae captured during the coastal survey showed some agreement with the summarized data from Sullivan Harbor but not with the Sheepscot estuary data. 


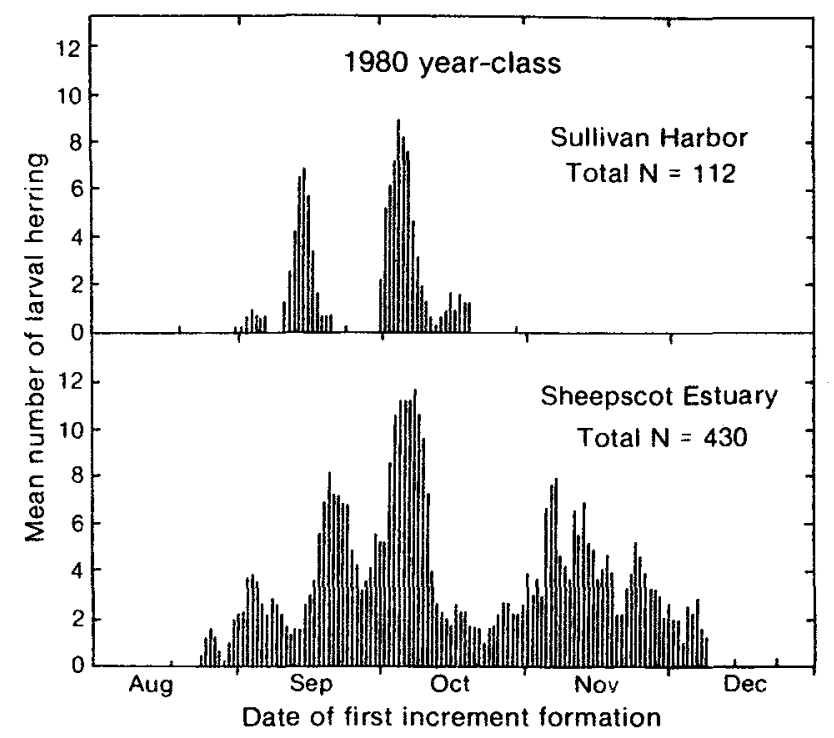

Fig. 10. Summarized frequencies of initial growth increments in otoltihs of larval herring from Sullivan Harbor and the Sheepscot estuary for the 1980 year-class.

\section{Discussion}

Analysis of catch rates and the appearance of cohorts of larval herring along the Maine coast indicated that larval production, and perhaps the abundance of spawning herring, declined after 1977. The decline was evident from the very low catch rates of larvae in 1978-81, the first low value in 1978 being coincident with a general increase in the catch of adult herring, and from the recent low levels of hatching in late autumn, particularly in 1981.

\section{Larval catch rates}

The increased catches of adult herring (age $4+$ ), which began in 1978 (Table 2), coincided with an abrupt decrease in larval catch rates along the Maine coast (Table 1). The catch in 1978 was especially unusual, because the largest contributor was the 1970 yearclass at age 8. Apart from the contribution of this year-class which was also appreciable during 1974-77, catches during the 1970's were largely composed of 4and 5-year-old fish. During 5 years of fishing (1974-78), the 1970 year-class supplied about $30 \%$ of the total harvest of ages 4-8 fish. As an explanation for the persistent abundance of the 1970 year-class, especially in 1976-78. Anthony and Waring (1980) suggested thast juveniles of this year-class tended to remain offshore and were not as available as was expected to the inshore fixed gears (stop seines and weirs) at ages 2 and 3 . Obviously, these herring became especially available to the mobile gear (purse seines) in 1978 and constituted about one-third of the relatively large catch of adult herring in that year (Table 2). This catch occurred mainly before the 1978 spawning season and coincided with the drastic

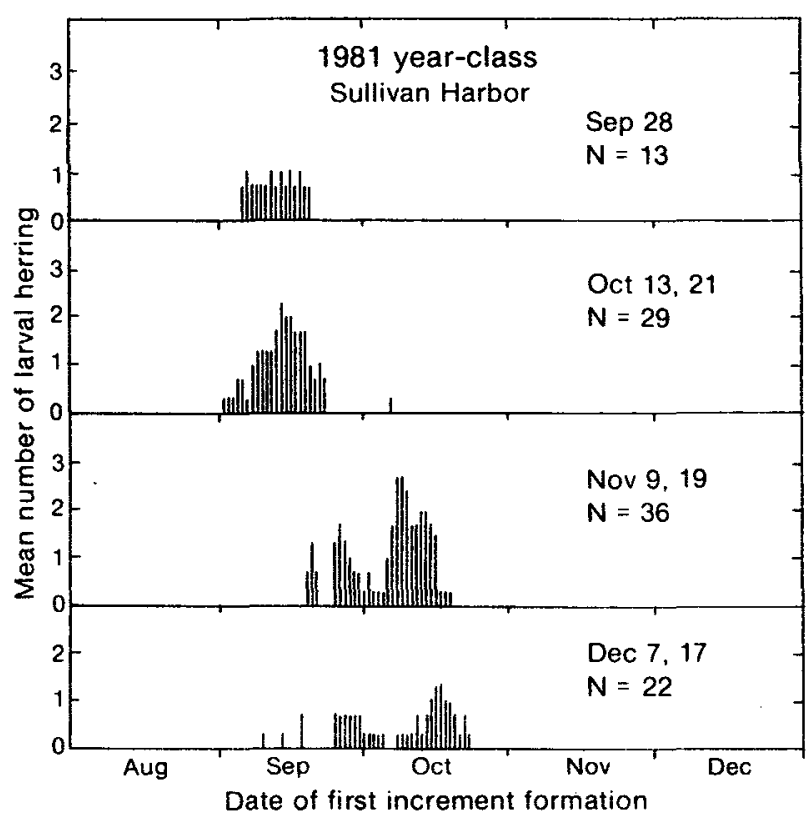

Fig. 11. Frequencies of initial growth increments in otoliths of larval herring from Sullivan Harbor, arranged by month of capture for the 1981 year-class.

decline in larval production in the autumn of that year (Table 1, Fig. 4). The low abundance of adult herring in 1979 due to the disappearance of the 1970 year-class, and the relatively high catches of young adults in 1980 and 1981, coincided with the apparently low level of larval production in these years. The reduced larval production extended to 1982 when it again coincided with a relatively large catch of adult herring (Graham and Crosby, MS 1983).

The occurrence of reduced catch rates in inshore waters after 1977 was apparently not related to a change in coastal transport of larvae, which might alter the abundance of larvae in the inshore sampling areas. The results of the coastal surveys (Fig. 6 and 7) indicated that spawning occurred on the same grounds in the early 1980's as in the 1970's, and larval distribution along the coast also appeared to be similar. More recent results of coastal surveys in eastern Maine (Graham et al., MS 1983) further supported these findings. The possibility that most of the larvae remained offshore in the late 1970's and early 1980's was considered unlikely. Although some larvae usually overwinter in offshore coastal waters and enter the estuaries and embayments in the spring (Graham et al., 1972), the spring catch rates in coastal waters beyond the headlands have been extremely low since the mid1970's and especially so in the early 1980's (Graham and Joule, MS 1981; unpubl. data for 1982-83).

Graham (1982) postulated that late spawning and hatching may increase the survival of larval herring along the Maine coast by shortening the period of 


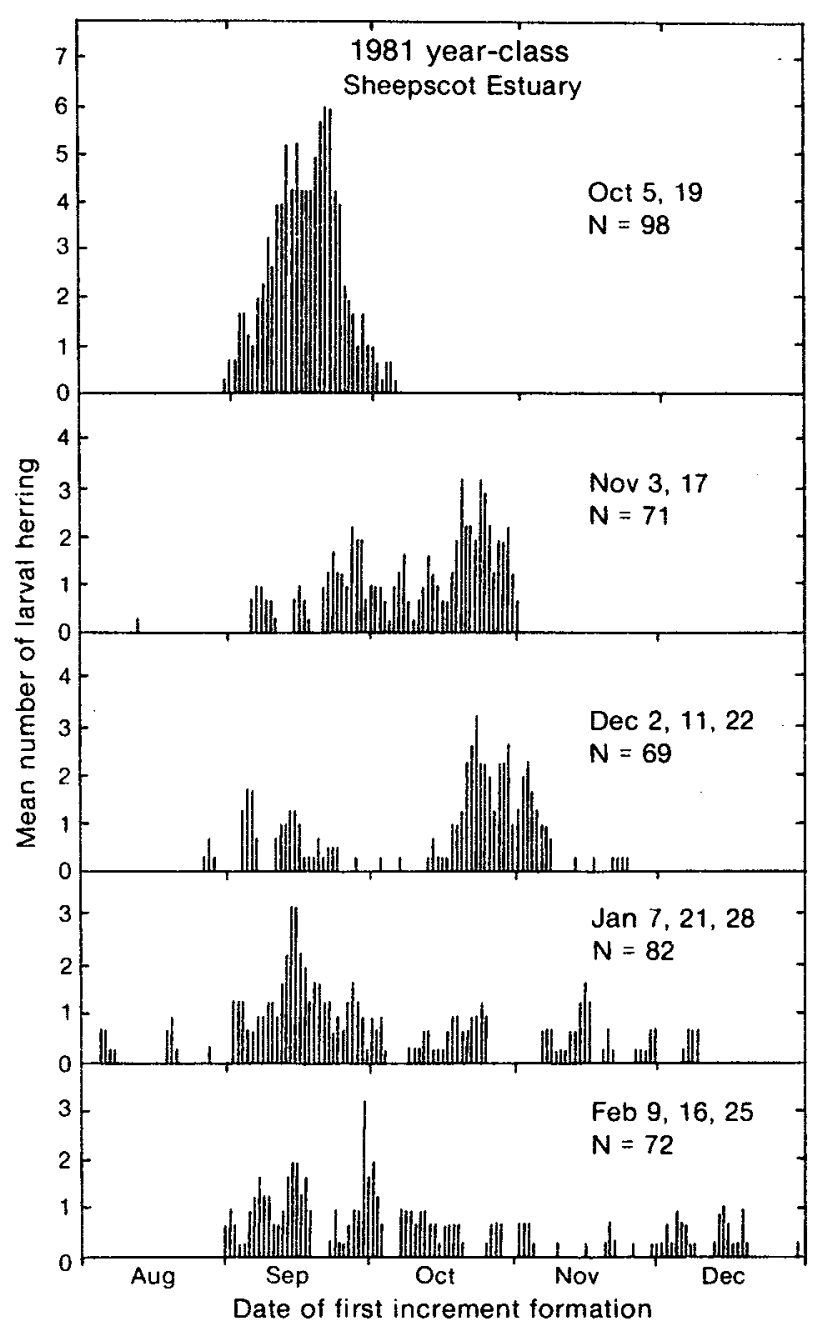

Fig. 12. Frequencies of initial growth increments in otoliths of larval herring from the Sheepscot estuary, arranged by month of capture for the 1981 year-class

winter mortality. During 1961-73, most larvae hatched in early autumn. During 1974-76 and 1978-79, the abundance of small larvae in winter catches indicated increased hatching in late autumn. In 1978, ageing of larvae by otolith growth increments supported this suggestion (Townsend and Graham, 1981), and, in 1980, confirmation of increased late spawning was evident by the appearance of cohorts of larvae in November and in early December (Fig. 9). However, these cohorts were missing in the 1981 data (Fig. 12). Furthermore, the scarcity of recently-hatched larvae in the central-western coastal waters during November 1981 , and the similarity of the larval distribution in 1981 to that in 1972 when there was little evidence of late spawning (Fig. 7), indicated that late autumn spawning was not prevalent in 1981. Catch records for the Maine fishery in 1983 indicate that the harvest of juvenile herring, of which the 1981 year-class should be the largest constituent, was one of the lowest in the 100year history of the Maine fishery for juveniles.

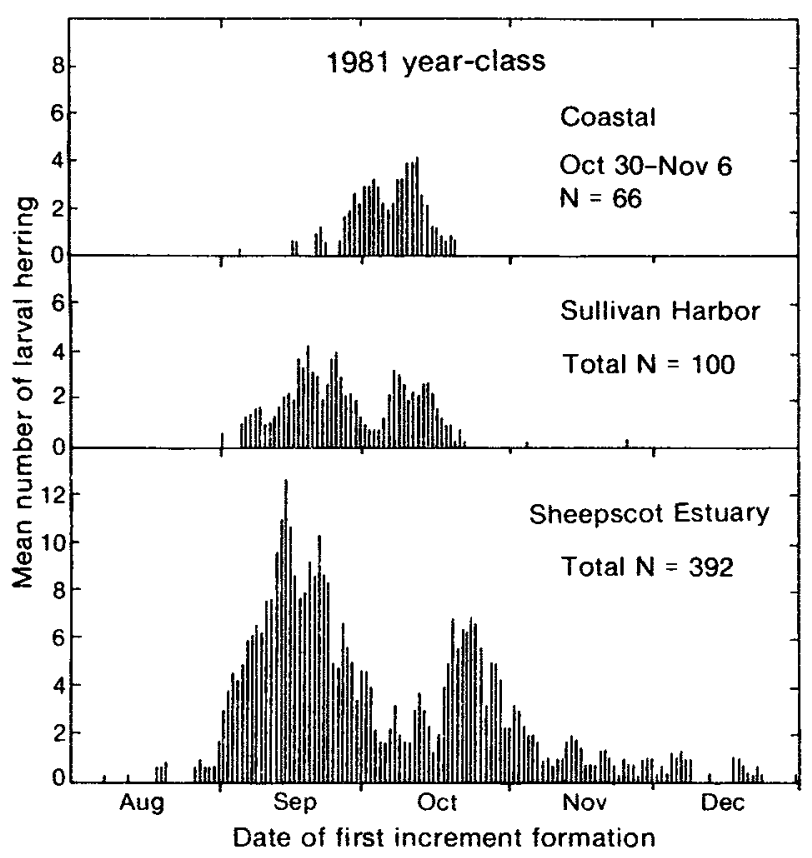

Fig. 13. Summarized frequencies of initial growth increments in otoliths of larval herring from Sullivan Harbor and the Sheepscot estuary for the 1981 year-class.

\section{Larval cohorts}

It would appear, a priori, that different cohorts of larvae originate through variation in the temporal and spatial deposition of eggs over a given spawning ground, i.e. they arise when a group of fish deposits eggs intermittently in an area or when several groups spawn in an area at different times. However, cohorts may also arise from intermittent periods of increased larval mortality over the spawning ground. Data from herring spawning on Georges Bank indicate that some retention of a given larval cohort occurs in the vicinity of its egg bed (Graham and Chenoweth, 1973). It is likely that the areas of concentration of newly-hatched larvae in eastern Maine are also generally indicative of spawning areas (Fig. 6), but these cohorts may fragment into smaller concentrations that are transported independently to various estuaries and embayments along the coast (Graham, 1982). These concentrations may maintain their integrity inshore, because it is common to find two discrete concentrations occupying the same narrow channel of an estuary. A few weeks after entering an estuary or embayment, the concentrations are drastically reduced and thinly dispersed through mortality (Graham, 1982). The surviving larvae reaggregate in early spring and metamorphose in late spring to form large schools of juveniles. The formation of such large schools of juveniles, following high mortality in autumn and winter (Graham, 1982), is probably the result of an integration of representatives of all available cohorts of larvae.

Previous studies of larval distributions have shown that some larval cohorts from spawning off eastern 
TABLE 2. Catches (metric tons) of juvenile and adult herring by age-group along the Maine coast in 1970-81. (Percentages represent the contribution of the 1970 year-class (bold type) to the catches in 1970-78.)

\begin{tabular}{|c|c|c|c|c|c|c|c|c|c|c|c|}
\hline \multirow{2}{*}{$\begin{array}{c}\text { Fishing } \\
\text { year }\end{array}$} & \multicolumn{4}{|c|}{ Juveniles by age-group } & \multicolumn{7}{|c|}{ Adults by age-group } \\
\hline & 1 & 2 & 3 & Total & 4 & 5 & 6 & 7 & 8 & $9+$ & Total \\
\hline 1970 & 294 & 6,258 & 4,422 & 10,974 & 2,673 & 513 & 726 & 294 & 265 & 118 & 4,589 \\
\hline 1971 & 1,909 & 2,838 & 1,731 & 6,478 & 3,388 & 1,793 & 409 & 127 & 126 & 86 & 5,929 \\
\hline 1972 & 3 & 17,360 & 833 & 18,196 & 492 & 242 & 318 & 264 & - & - & 1,316 \\
\hline 1973 & 164 & 8,100 & 7,456 & 15,720 & 193 & 164 & 80 & 121 & 55 & 66 & 679 \\
\hline 1974 & 486 & 9,074 & 5,489 & 15,049 & 3,780 & 230 & 75 & 9 & - & - & 4,094 \\
\hline 1975 & 796 & 9,451 & 2,537 & 12,785 & 924 & 1,249 & 96 & 8 & 120 & - & 2,397 \\
\hline 1976 & 478 & 13,228 & 12,740 & 26,446 & 1,203 & 1,122 & 1,390 & 11 & 6 & 16 & 3,748 \\
\hline 1977 & 1,316 & 18,541 & 8,022 & 27,879 & 2,161 & 535 & 381 & 1,358 & 3 & 40 & 4,478 \\
\hline 1978 & 242 & 12,398 & 8,025 & 20,665 & 1,816 & 2,969 & 388 & 739 & 3,055 & 210 & 9,177 \\
\hline 1979 & 27 & 25,839 & 11,485 & 37,351 & 1,708 & 191 & 329 & 196 & 104 & 179 & 2,707 \\
\hline 1980 & 1,012 & 9,051 & 26,538 & 36,601 & 8,606 & 442 & 24 & 101 & - & 133 & 9,306 \\
\hline 1981 & 120 & 39,575 & 1,627 & 41,322 & 1,586 & 3,815 & 366 & 20 & 20 & 120 & 6,927 \\
\hline Percent & 33.6 & 17.8 & 14.5 & 17.3 & 22.7 & 14.1 & 35.9 & 46.3 & 84.2 & & $29.9^{\mathrm{a}}$ \\
\hline
\end{tabular}

a Percent based on age-groups $4-8$ in $1970-78$.

Maine mixed with those from central and western Maine through their transport westward by coastal currents (Graham et al., 1972; Graham, 1982). Possible evidence of such mixture is indicated by the presence in Sheepscot estuary during October 1980 of a modal group which had dates of initial formation similar to those found in Sullivan Harbor (Fig. 8-10).

\section{Spawning grounds}

Larvae from the spawning grounds in eastern and central-western Maine recruit as juveniles to the same coastal fishery, although the dynamics of larval production may make these two spawning areas independently important. Larval survival and subsequent recruitment to the fishery may be enhanced by different mechanisms (dispersion and late spawning) in the two areas. The location of the eastern spawning ground permits dispersion of larvae westward to the many estuaries and embayments (Fig. 6), potentially resulting in reduced density-dependent mortality in the autumn. Such a possibility is lessened for larvae produced on the central-western spawning ground by their entrance into estuaries and embayments relatively close to the ground. Late spawning apparently enhances winter survival in central-western Maine (Graham, 1982) but not necessarily in eastern Maine. Spawning usually begins earlier in eastern Maine, and larvae from late spawning should occur there in November rather than in the winter months as in the central-western region. However, data from Sullivan Harbor show little evidence of late spawning except perhaps in 1981 (Fig. 5), but this peak in November is only superficial because of the scarcity of larvae from early spawning in September-October. Even if spawning in late autumn occurs in the eastern region, it was not evident from the December catch rates in Sullivan Harbor nor from the results of a survey along the eastern Maine coast in 1982 (Graham et al., MS 1983), which indicated that only traces of newly hatched lar- vae were present there in late November. In contrast, data from the Sheepscot estuary of central Maine show secondary peak catch rates in winter (December-February) from late spawning in years when the usual early autumn peaks in catch rates occurred (Fig. 4, 10).

Spawning evidently persisted on the same grounds for as long as 10 years (Fig. 6, 7) and even longer if the consistent timing in the shoreward movement of larvae into the Sheepscot estuary is considered indicative of such persistency (Graham et al., 1972). Indeed, in eastern Maine, herring eggs were obtained from several localities on the spawning ground by fishermen who can predict from many years of experience that, in certain locations, eggs will appear on their lobster traps at a particular time of year (Stevenson, MS 1984). Egg deposition occurs at some of these locations in every year but not at others. The distributions of newly-hatched larvae from coastal surveys indicate that at least two major spawning areas existed within the spawning ground of eastern Maine in 1972 (Graham, 1982), possibly in 1980 (Fig. 6), and in 1982 (Graham et al., MS 1983) when the temporal abundance of larvae indicated that the time of spawning differed for the two areas. Possibly, the presence of different cohorts of larvae in inshore waters reflects the spawning consistency of Gulf of Maine herring. In the autumns of 1980 and 1981 (Fig. 10,13), concentrations from two cohorts of larvae were present in Sullivan Harbor, which receives larvae from eastern Maine spawning (Graham, 1982). Their mean temporal separation (20 days) was the same for both years. In the Sheepscot estuary, concentrations from two or three cohorts were also present during autumn in these years, but their temporal separation was about 16 days in 1980 and 34 days in 1981. Two or three cohorts are consistently present in Sheepscot estuary during the autumn, as indicated by length frequencies (Graham et al., 1972) and more recently by ageing (Townsend and Graham, 1981). 


\section{Management implications}

The consistently low catch rates of larvae in inshore waters since 1977 are a cause for concern, because they reflect a substantial decline in the abundance of spawning herring along the coast. Possibly, there is a minimum viable population of herring which, like other animals (Shaffer, 1981), exists under average environmental conditions but is susceptible to virtual extinction due to environmental perturbations which may be enhanced by fishing pressure. It would be difficult to anticipate a collapse of the herring population, because (a) recruitment to the fishery for juveniles bears little or no relation to spawning stock size, and (b) depletion might occur progressively within individual spawning groups rather than at the same time along the entire coast. Recruitment in the 1970's was often equivalent to that in the 1960's when the spawning population was relatively large (Anthony and Waring, 1980). Although the 1979 year-class yielded a particularly large catch of juveniles $(39,600$ tons in 1981 (Table 2), it was produced during a period of low autumnal abundance of larvae (Fig. 3). The success of this year-class was probably related to high survival of late-hatched larvae, as indicated by the increase in larval catch rates (Fig. 4) in January (Graham, 1982). Low catch rates and the virtual absence of cohorts in the Sheepscot estuary from late spawning in 1981 (Fig. 4, 12) preceded the collapse of the 1983 fishery for juvenile herring (at age 2). In contrast, larval catch rates in Sullivan Harbor, although low in September 1981, were higher in November than those of 1973-74 and 1980 when no collapse occurred. The Sheepscot estuary received its larvae from the centralwestern spawning ground and those in Sullivan Harbor were from the eastern ground. Possibly, the poor recruitment of age 2 juveniles to the 1983 fishery was related to poor larval production from only one of the spawning grounds rather than from all three along the coast. The decline and collapse of the herring fishery on Georges Bank was documented by Anthony and Waring (1980). They attributed the demise of this herring population to overfishing the individual spawning concentrations, noting that overfishing proceeded progressively from west to east across the bank. This claim was substantiated by pointing out the coincident severe decrease in egg deposition and the progressive west to east decline in catch rates of larvae. Grimm (1983) noted that the collapse of Georges Bank spawning population of herring occurred during a period of high water temperatures over the traditional spawning beds and postulated that the large volume of warm water may have affected spawning and hatching success or caused the herring to alter their migration patterns. Selgeby (1982) reported that overexploitation of spawning units caused the collapse of the lake herring (Coregonus artedii) fishery in Lake Superior.

The major aspect of herring management in coastal waters by the State of Maine is the prohibition of fishing for adult herring during the spawning season. Although this procedure permits those adult herring which survive the prespawning harvest to aggregate on the spawning grounds and deposit their eggs, it does not control the size of the harvest. Meaningful catch limitations are difficult to establish on a continuing basis, and none were included in the 1983 regulations (Anon., 1983). A State regulation of long-standing restricts purse-seining in coastal waters along a large part of eastern Maine, but its purpose is to protect the harvest of weirs and stop seines in inshore waters. Whether this regulation is also helpful in conserving the herring which spawn off eastern Maine is difficult to determine, because herring which spawn in that region probably are harvested along other parts of the coast at other times of the year. Whether adult herring form discrete spawning units along the coast is uncertain, although the continued long-term use of spawning grounds and the persistence of similar numbers of cohorts of larvae inshore each year might indicate their existence. However, some adult herring migrate extensively along the coast (Creaser et al., 1984). The probability of considerable intermixture of herring from widely separated areas of the Gulf of Maine was reviewed by Sindermann (MS 1979).

The intermixture of herring from various parts of the coast poses management problems. Failure of the fishery for juveniles along the entire coast in a given year may be due to poor larval production from a spawning ground in one sector of the coast. For example, the low catch of 2-year-old herring in 1983 was perhaps related to poor larval production in centralwestern Maine. Under such generally low larval production that has prevailed after 1977, low levels of spawning on different grounds may be responsible for low harvests in different years. If individual spawning units exist, their mixture in the catches along the coast would permit the demise of a weak unit without the knowledge of fishery managers. Also recruitment failure to the harvest of juveniles in central-western Maine may be especially difficult to anticipate. Production of larvae in eastern Maine may be sufficient to mask such failure, because larvae which are transported westward from the eastern spawning ground metamorphose into juveniles in the central-western area. It is important, therefore, to understand the interrelations of herring which spawn on different grounds along the coast.

\section{Acknowledgements}

The authors are indebted to Nancy Hurst, Sally Sherman, Laurice Churchill and Kristin Geib who prepared the data for processing, to Margaret Hunter for computer-processing of much of the data, and especially to David K. Stevenson for his careful review of the initial manuscript. 


\section{References}

ANON. 1983. Herring regulations. Maine Dept. Mar. Resour., 3 p.

ANTHONY, V. A., and G. WARING. 1980. The assessment and management of the Georges Bank herring fishery. ICES Rapp. Proc.Verb., 177: 72-111

CREASER, E. P., D. A. LIBBY, and G. D. SPEIRS. 1984. Seasonal movements of juvenile and adult herring, Clupea harengus $\mathrm{L}$., tagged along the Maine coast. J. Northw. Atl. Fish. Sci, 5: 71-78.

DUNN, O.J. 1964. Multiple comparisons using rank sums. Technometrics, $6: 241-252$.

FOGARTY, M. J., and S. H. CLARK. MS 1984. Status of Atlantic herring resources in the Gulf of Maine region, 1983. U. S. Nat. Mar. Fish. Serv., Northeast Fisheries Center, Woods Hole Lab. Ref. Doc., No 83-46, $33 \mathrm{p}$.

GEFFEN, A. J. 1982. Otolith ring deposition in relation to growth rate in herring (Clupea harengus) and turbot (Scophthalmus maximus) larvae. Mar. Biol., 71: 317-326.

GJOSETER, H. MS 1981. Dagsonelesing som metode i aldersstudier pa fisk, med eksempler pa anvendelse pa tropiske og boreale arter. Thesis, Univ. of Bergen, Norway, $172 p$.

GJOSETER, H., and V. ØIESTED. MS 1981. Growth patterns in otoliths as an indication of daily growth variations of larval herring (Clupea harengus) from an experimental ecosystem. ICES C.M., Doc. No. H:31, $9 \mathrm{p}$

GRAHAM, J. J. 1972. Retention of larval hering within the Sheepscot estuary of Maine. Fish. Bull. U. S., 70: 299-305.

1982. Production of larval herring, Clupea harengus, along the Maine coast, 1964-78. J. Northw. Atl. Fish. Sci., 3: 63-85.

GRAHAM, J. J., and S. B. CHENOWETH. 1973. Distribution and abundance of larval herring, Clupea harengus harengus Linnaeus, over egg beds on Georges Bank. ICNAF Res. Bull., 10: 141-149.

GRAHAM, J. J., and C. L. CROSBY. MS 1983. Evaluation of the 1982 larval year-class of herring along coastal Maine. Maine Dept. Mar. Resour. Lab. Ref. Doc., No. 83-16, 20 p.
GRAHAM, J. J., and B. J. JOULE. MS 1981. Preliminary evaluation of the 1980 larval year-class strength of coastal Maine herring. NAFO SCR Doc., No. 140, Serial No. N447, 22 p.

GRAHAM, J. J., S. B. CHENOWETH, and C. W. DAVIS. 1972. Abundance, distribution, movements and lengths of larval herring along the western coast of the Gulf of Maine. Fish. Bull. U. S., 70: 307-321.

GRAHAM, J. J., D. W. TOWNSEND, and D. K. STEVENSON. MS 1983. Larval herring surveys in Maine (USA) and New Brunswick (Can.) waters of the eastern Gulf of Maine. NAFO SCRDOC., No.67, Serial No. N732, 8 p.

GRIMM, S. K. 1983. Changes in time and location of herring, Clupea harengus L., spawning relative to bottom temperature in the Georges Bank and Nantucket Shoals areas, 1971-77. NAFO Sci. Coun. Studies, 6: 15-34.

LOUGH, G. R., M. PENNINGTON, G. R. BOLZ, and A. A. ROSENBURG. 1982. Age and growth of larval Atlantic herring, Clupea harengus L., based on otolith growth increments. Fish. Bull. U.S.., 80: $187-199$.

SELGEBY, J. H. 1982. Decline of lake herring (Coregonus artedii) in Lake Superior: an analysis of the Wisconsin herring fishery, 1963-78. Can. J. Fish. Aquat. Sci., 39: 554-563.

SHAFFER, M. L. 1981. Minimum population sizes for species conservation. Bio-Science, 31: 131-134.

SINDERMANN, C. J. MS 1979. Status of Northwest Atlantic herring stocks of concern to the United States. U.S. Nat. Mar. Fish. Serv. Tech. Rep., No. 23, 449 p.

STEVENSON, D. K. MS 1984. Locations of Atlantic herring, Clupea harengus L., egg beds in eastern Maine. Maine Dept. Mar. Resour. Lab. Ref. Doc., No. 84-2, 3 p.

TOWNSEND, D. W., and J. J. GRAHAM. 1981. Growth and age structure of larval herring, Clupea harengus, in the Sheepscot River estuary, Maine, as determined by daily growth increments in otoliths. Fish. Bull. U.S., 79: 123-130.

ZAR, J. H. 1974. Biostatistical analysis. Prentice-Hall, Inc., Englewood Cliffs, N. J., 620 p. 